\title{
SHORT
}

COMMUNICATIONS

\section{Ethyl Diazoacetate in Catalytic Reactions with Imides: Experimental and Calculation Data}

\author{
Vs. V. Nikolaev ${ }^{1}$, L. Hennig ${ }^{2}$, A. K. Croft $^{3}$, B. Schulze ${ }^{2}$, R. R. Kostikov ${ }^{1}$, and V. A. Nikolaev ${ }^{1}$ \\ ${ }^{1}$ St. Petersburg State University, Universitetskii pr. 26, St. Petersburg, 198504 Russia \\ e-mail:vnikola@VN6646.spb.edu \\ ${ }^{2}$ Universität Leipzig, Institut für organische Chemie, Leipzig, Germany \\ ${ }^{3}$ University of Wales, Department of Chemistry, Bangor, Great Britain
}

Received November 30, 2004

In continuation of our studies in the field of catalytic reactions of diazo carbonyl compounds with imides having an $\mathrm{NH}$ group [1], the present communication reports on the effect of the reactant structure on the direction of catalytic decomposition of ethyl diazoacetate in the presence of saccharin (Ia), phthalimide (Ib), and maleimide (Ic). In addition, we performed calculations of the stability of $\mathrm{O}$ - and N-ylides as possible intermediates.

Catalytic decomposition of ethyl diazoacetate (II) with dirhodium tetraacetate [2] in the presence of saccharin (Ia) and phthalimide (Ib) afforded only the corresponding ethoxycarbonylmethyl imidates IIIa and IIIb, respectively, resulting from O-alkylation of the carbonyl group in the substrate, as well as diethyl maleate and dimethyl fumarate formed by dimerization of intermediate ethoxycarbonylcarbene (Scheme 1).

Scheme 1.<smiles>[X]c1ccccc1C(=O)N=C=N[NH2+]</smiles>

la, lb

II

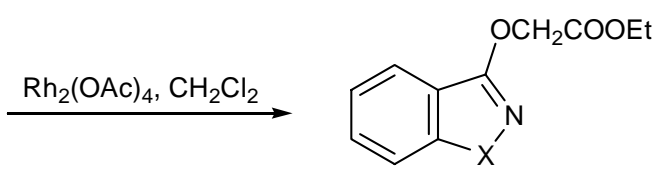

IIIa, IIIb

$$
\mathrm{X}=\mathrm{SO}_{2}(\mathbf{a}), \mathrm{CO}(\mathbf{b}) \text {. }
$$

Obviously, as in the catalytic decomposition of diazo dicarbonyl compounds [1], the process involves intermediate formation of carbonyl ylides [3] which are stabilized via intramolecular [1,4]-migration of the imide hydrogen atom [4].

An analogous reaction of diazo ester II with maleimide (Ic) gave cycloadduct IV due to participation of two maleimide molecules (Scheme 2). The structure of IV was determined by ${ }^{1} \mathrm{H}$ and ${ }^{13} \mathrm{C}$ NMR spectroscopy using APT pulse sequence and COSY, HMQC, HMBC, and NOESY techniques. The exo configuration of IV was confirmed by NOE experiments on 1-H, $5-\mathrm{H}$, and $4-\mathrm{H}(\delta 3.73,3.85$, and $4.81 \mathrm{ppm}$, respectively). Spirocyclic compound IV is likely to be formed via intermolecular 1,3-cycloaddition of the primary adduct, carbonyl ylide $\mathbf{B}$, at the double bond of the second maleimide molecule.

Our experimental data indicate that the attack by rhodium(II) intermediate $\mathbf{A}$ is directed at the carbonyl oxygen atom in imide substrate $\mathbf{I a}-\mathbf{I c}$ to give carbonyl
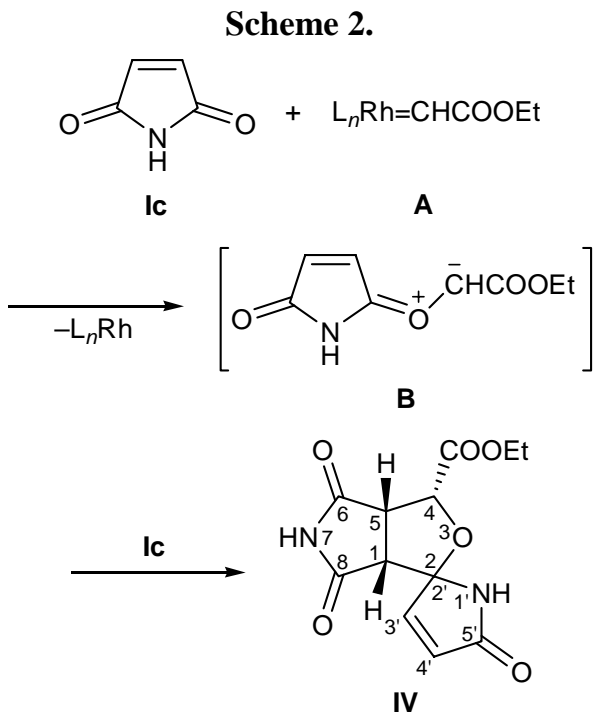
ylide B. An alternative path including addition of intermediate $\mathbf{A}$ at the imide nitrogen atom with formation of ammonium ylide $\mathbf{C}$ does not occur or its contribution is insignificant (Scheme 3).

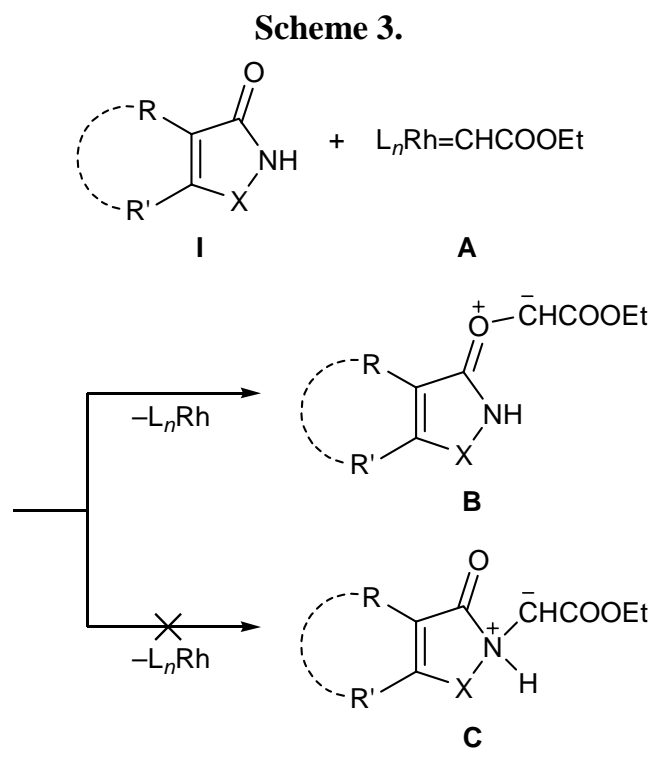

In keeping with the experimental data, DFT calculations (B3LYP/6-31G*, Gaussian 03) showed that O-ylide $\mathbf{B}$ generated from maleimide and methoxycarbonylcarbene is more stable (by $49 \mathrm{~kJ} / \mathrm{mol}$ ) than the corresponding N-ylide C. Analogous results were also obtained for the other imides.

Ethyl (1,1-dioxo-1H-1 $\lambda^{6}$-benzo[d]isothiazol-3-yloxy)acetate (IIIa). Dirhodium tetraacetate, $7 \mathrm{mg}$ $(15.8 \mu \mathrm{mol})$, was added to a suspension of $0.5 \mathrm{~g}$ $(2.7 \mathrm{mmol})$ of saccharin (Ia) in $8 \mathrm{ml}$ of methylene chloride, and a solution of $0.66 \mathrm{~g}(5.4 \mathrm{mmol})$ of ethyl diazoacetate (II) in $4 \mathrm{ml}$ of methylene chloride was then added over a period of 30 min under stirring at $18-20^{\circ} \mathrm{C}$. The mixture was stirred for $20 \mathrm{~min}$, the solvent was distilled off to a volume of $\sim 3 \mathrm{ml}$, the residue was filtered through a thin layer of silica gel to remove the catalyst, the filtrate was dried over $\mathrm{MgSO}_{4}$ and evaporated, and the residue was recrystallized from methylene chloride-petroleum ether $(2: 1)$. Yield $0.57 \mathrm{~g}\left(80 \%\right.$ ), colorless crystals, $\mathrm{mp} 76-77^{\circ} \mathrm{C}$ (from $\mathrm{CH}_{2} \mathrm{Cl}_{2}$-petroleum ether). ${ }^{1} \mathrm{H}$ NMR spectrum $\left(\mathrm{CDCl}_{3}\right.$, $0.3 \mathrm{M}), \delta$, ppm: $1.31 \mathrm{t}\left(3 \mathrm{H}, \mathrm{OCH}_{2} \mathrm{CH}_{3}, J=7.2 \mathrm{~Hz}\right)$, $4.3 \mathrm{q}\left(2 \mathrm{H}, \mathrm{OCH}_{2} \mathrm{CH}_{3}, J=7.2 \mathrm{~Hz}\right), 5.1 \mathrm{~s}\left(2 \mathrm{H}, \mathrm{CH}_{2} \mathrm{CO}\right)$, 7.73-7.9 m (4H, $\left.\mathrm{H}_{\text {arom }}\right)$. Found, \%: C 49.09; H 4.13; $\mathrm{N}$ 5.25. $\mathrm{C}_{11} \mathrm{H}_{11} \mathrm{NO}_{5} \mathrm{~S}$. Calculated, \%: C 49.07; $\mathrm{H} 4.11$; N 5.20.

Ethyl (3-oxo-3H-isoindol-1-yloxy)acetate (IIIb). The reaction was performed as described above for compound IIIa using $1.0 \mathrm{~g}(6.8 \mathrm{mmol})$ of phthalimide
(Ib) and $10 \mathrm{mg}(22.6 \mu \mathrm{mol})$ of dirhodium tetraacetate in $10 \mathrm{ml}$ of methylene chloride; a solution of $1.54 \mathrm{~g}$ (13.5 mmol) of ethyl diazoacetate (II) in $30 \mathrm{ml}$ of methylene chloride was added over a period of $4 \mathrm{~h}$, the mixture was stirred for $20 \mathrm{~min}$ and concentrated to a volume of $\sim 5 \mathrm{ml}$, unreacted phthalimide $(0.14 \mathrm{~g})$ was separated by filtration, the filtrate was evaporated, and the residue was recrystallized from methylene chloride (3 $\mathrm{ml})$ to isolate $0.3 \mathrm{~g}(31 \%$ on the reacted phthalimide) of compound IIIb. The mother liquor was subjected to column chromatography on silica gel (5 g) using methylene chloride as eluent) to isolate $0.25 \mathrm{~g}$ of phthalimide and a mixture of diethyl fumarate and diethyl maleate at a ratio of $\sim 10: 1$, which were identified by ${ }^{1} \mathrm{H}$ NMR spectroscopy, $\delta(\mathrm{CH}=) 6.78$ and $6.18 \mathrm{ppm}$, respectively. Compound IIIb: colorless crystals, mp $109-111^{\circ} \mathrm{C}$ (from methylene chloride). ${ }^{1} \mathrm{H}$ NMR spectrum $\left(\mathrm{CDCl}_{3}, 0.3 \mathrm{M}\right), \delta, \mathrm{ppm}: 1.31 \mathrm{t}(3 \mathrm{H}$, $\left.\mathrm{OCH}_{2} \mathrm{CH}_{3}, J=6.9 \mathrm{~Hz}\right), 4.28 \mathrm{q}\left(2 \mathrm{H}, \mathrm{OCH}_{2} \mathrm{CH}_{3}, J=\right.$ $6.9 \mathrm{~Hz}), 5.18 \mathrm{~s}\left(2 \mathrm{H}, \mathrm{CH}_{2} \mathrm{CO}\right), 7.59-7.75 \mathrm{~m}\left(4 \mathrm{H}, \mathrm{H}_{\text {arom }}\right)$. Found, \%: C 61.90; $\mathrm{H} 4.84 ; \mathrm{N}$ 6.09. $\mathrm{C}_{12} \mathrm{H}_{11} \mathrm{NO}_{4}$. Calculated, \%: C 61.81; H 4.75; N 6.00.

Decomposition of ethyl diazoacetate (II) in the presence of maleimide (Ic). Dirhodium tetraacetate, $5 \mathrm{mg}$, was added to a solution of $0.2 \mathrm{~g}(2 \mathrm{mmol})$ of maleimide (Ic) in $5 \mathrm{ml}$ of methylene chloride, and a solution of $0.12 \mathrm{~g}(1 \mathrm{mmol})$ of ethyl diazoacetate (II) in $15 \mathrm{ml}$ of methylene chloride was then added dropwise over a period of $30 \mathrm{~min}$ under stirring. The mixture was stirred for $30 \mathrm{~min}$, concentrated to a volume of $\sim 2-3 \mathrm{ml}$, and passed through a thin layer of silica gel. Elution with methylene chloride gave $0.03 \mathrm{~g}$ of a mixture of diethyl maleate and diethyl fumarate, $0.165 \mathrm{~g}$ of adduct $\mathbf{I V}$, and $0.07 \mathrm{~g}$ of unreacted maleimide (Ic).

Ethyl 5',6,8-trioxo-2',5'-dihydro-1'H-3-oxa-7azabicyclo[3.3.0] octane-2-spiro-2'-pyrrole-4-carboxylate (IV). Yield $0.165 \mathrm{~g}$ (87\% on the reacted maleimide), mp $222-224^{\circ} \mathrm{C}$ (from methylene chloride). IR spectrum, $v, \mathrm{~cm}^{-1}\left(I_{\text {rel }}, \%\right): 3403$ (60), 3313 (70), 3131 (75), 3058 (76), 2933 (79), 1783 (73), 1644 (79), 1633 (79), 1409 (82), 1349 (62), 1272 (76), 1076 (68), 1031 (70), 809 (82). ${ }^{1} \mathrm{H}$ NMR spectrum (DMSO- $\left.d_{6}, 0.3 \mathrm{M}\right), \delta$, ppm: $1.21 \mathrm{t}\left(3 \mathrm{H}, \mathrm{OCH}_{2} \mathrm{CH}_{3}, J=\right.$ $7.0 \mathrm{~Hz}), 3.73 \mathrm{~d}(1 \mathrm{H}, 1-\mathrm{H}, J=9.6 \mathrm{~Hz}), 3.85 \mathrm{~d} . \mathrm{d}(1 \mathrm{H}$, $5-\mathrm{H}, J=4.6,9.6 \mathrm{~Hz}), 4.17 \mathrm{q}\left(2 \mathrm{H}, \mathrm{OCH}_{2} \mathrm{CH}_{3}, J=\right.$ $7.0 \mathrm{~Hz}), 4.81 \mathrm{~d}(1 \mathrm{H}, 4-\mathrm{H}, J=4.6 \mathrm{~Hz}), 6.07 \mathrm{~d}\left(1 \mathrm{H}, 4{ }^{\prime}-\mathrm{H}\right.$, $J=5.4 \mathrm{~Hz}), 7.13 \mathrm{~d}\left(1 \mathrm{H}, 3^{\prime}-\mathrm{H}, J=5.4 \mathrm{~Hz}\right), 8.95 \mathrm{~s}$ $\left(1 \mathrm{H}, 11^{\prime}-\mathrm{H}\right), 11.37 \mathrm{~s}(1 \mathrm{H}, 7-\mathrm{H}) .{ }^{13} \mathrm{C}$ NMR spectrum (DMSO- $\left.d_{6}\right), \delta$, ppm: $13.9\left(\mathrm{CH}_{3} \mathrm{CH}_{2} \mathrm{O}\right), 51.02\left(\mathrm{C}^{1}\right)$, $51.06\left(\mathrm{C}^{5}\right), 61.5\left(\mathrm{CH}_{3} \mathrm{CH}_{2} \mathrm{O}\right), 76.7\left(\mathrm{C}^{4}\right), 98.3\left(\mathrm{C}^{2}\right)$, $126.8\left(\mathrm{C}^{4}\right), 148.6\left(\mathrm{C}^{3}\right), 169.4(\mathrm{CO}), 171.2\left(\mathrm{C}^{5^{\prime}}\right), 173.7$ 
$\left(\mathrm{C}^{6}\right), 176.9\left(\mathrm{C}^{8}\right)$. Mass spectrum, $\mathrm{m} / \mathrm{z}\left(I_{\mathrm{rel}}, \%\right): 280$ (45.0) $[M]^{+}, 244$ (6.4), 212 (100), 154 (39.4), 138 (34.7), 136 (30.5), 77 (19.7). Found, \%: C 51.47; $\mathrm{H}$ 4.36; $\mathrm{N}$ 10.03. $\mathrm{C}_{12} \mathrm{H}_{12} \mathrm{~N}_{2} \mathrm{O}_{6}$. Calculated, \%: C 51.44; $\mathrm{H} 4.31$; N 9.99 .

The ${ }^{1} \mathrm{H}$ and ${ }^{13} \mathrm{C}$ NMR spectra were recorded on Varian Gemini 200, Gemini 300, and Bruker DRX-600 Avance spectrometers at 200,300, and $600 \mathrm{MHz}$, respectively, for ${ }^{1} \mathrm{H}$ and at $50.3,75.45$, and $150.92 \mathrm{MHz}$, respectively, for ${ }^{13} \mathrm{C}$; TMS was used as internal reference. The mass spectra (electron impact, $70 \mathrm{eV}$ ) were obtained with direct sample admission into the ion source. The IR spectra were measured in $\mathrm{KBr}$ on an ATI Mattson Genesis Series FTIR instrument.

\section{REFERENCES}

1. Schulze, B., Nikolaev, Vs.V., Hennig, L., Rodina, L.L., Sieler, J., and Nikolaev, V.A., Russ. J. Org. Chem., 2004, vol. 40, p. 740.

2. Doyle, M.P., McKervey, M.A., and Ye, T., Modern Catalytic Methods for Organic Synthesis with Diazo Compounds, New York: Wiley, 1998.

3. Padwa, A. and Hornbuckle, S.F., Chem. Rev., 1991, vol. 91, p. 263; McMills, M.C. and Wright, D., Synthetic Applications of 1,3-Dipolar Cycloaddition Chemistry, Padwa, A., Ed., Haboken, NJ: Wiley, 2003, p. 253.

4. Lottes, A.C., Landgrebe, J.A., and Larsen, K., Tetrahedron Lett., 1989, vol. 30, p. 4089; Busch-Petersen, J. and Corey, E.J., Org. Lett., 2000, vol. 2, p. 1641. 